\title{
Investigation of the Implementation of Green Manufacturing on Textile Industry in West Java
}

\author{
Supriyadi, Ratna Ekawati \\ STIE STEMBI - Bandung \\ Email: supriyadi@stiestembi.ac.id
}

\begin{abstract}
Awareness to preserve the environment in the production process, so-called green manufacturing, is a challenge for the manufacturing industry. This study aims to analyze the factors that encourage the implementation of green manufacturing in the textile industry in West Java. We also examined the impact on profitability. This is a research with a quantitative approach. Data were collected by questionnaire. A total of 102 textile companies involved as the sample, selected randomly. The analytical method used is multiple regression. The results showed that the stakeholder pressures consisting of competitor pressures, government pressure, social pressure, customer pressure, encouragement of suppliers, and management awareness, are significantly influence the implementation of green manufacturing in the textile industry in West Java. Other findings, that the implementation of green manufacturing has a positive and significant impact on improving the profitability of the company. The results of this research is preliminary information, both for further research, as well as for decision making by the relevant authorities.
\end{abstract}

Keywords - Green Manufacturing, Stakeholder Pressure, Profitability

\section{INTRODUCTION}

The textile industry is one of the largest contributors to national income in Indonesia. The competitiveness of Indonesian textile industry is relatively good. This is a potential that must be maintained, while continuing to be strengthened in order to become one of the leading sector for the economy of Indonesia. Another advantage, the textile industry employs many workers [1].

Referring to sustainability development, the government has outlined a policy for the industry to implement green manufacturing, through to Law No. 32 of 2009, concerning the protection and management of the environment [2]. This means the development of textile industry should also pay attention to environmental sustainability. Therefore it is proper the textile industry to implement the concept of green manufacturing.

However, until now, the implementation of the concept of green manufacturing, is not optimal by industry, including the textile industry. In West Java, the data shows there are still many cases lack of implementation of green manufacturing [3].

The purpose of this study is to analyze how the implementation of green manufacturing in the textile industry in West Java. It also analyzed the influence of stakeholder pressure on the implementation of green manufacturing, as well as the impact on the profitability of the company.

\section{LITERATURE REVIEW}

\section{A. The Concept of Green Manufacturing}

The concept of green manufacturing is inseparable from the awareness of the importance of maintaining environmental sustainability. This is triggered by the growing sustainable development issues. The word sustainability was first introduced in the context of sustainable development defined by the United Nations in 1987 as follows [4]: "sustainable development is a development that meets the needs of the present without compromising the ability of future generations to meets their own needs".

Furthermore the term corporate sustainability, which can be interpreted as adopting business strategies and activities that meet the needs of companies and stakeholders while protecting, sustaining and improving human and natural resources that will be needed in the future [5].

Literature about sustainability emphasizes the need for systematic thinking to conserve natural resources, eliminate poverty, the promotion of equality, and reducing population growth and improving quality of life [6].

In the functional areas, then developed terms refer to efforts to achieve the sustainability concept. In the field of marketing, there is the term green marketing and green shopper. In manufacturing the term green operation and green production and green manufacturing. In the field of construction engineering technology, the term green building.

Green manufacturing is a term that refers to a new paradigm in manufacturing. The term green manufacturing was coined to reflect the new manufacturing paradigm that employs various green strategies and techniques to become more eco-efficient. These strategies include creating products/systems that consumes less material and energy, substituting input materials (e.g. non-toxic for toxic, renewable for non-renewable), reducing unwanted outputs and converting outputs to inputs (recycling) [7].

Another term is green production. It applies the principles of environmental protection and energy conservation to production activities to reduce industrial waste, save energy and resource, and minimize pollution, while accomplishing desired production economy [8].

Refers to two terms, the main essence is that the new paradigm in the manufacturing industry are answering the challenge to realize a strategy to ensure that the production process to be more efficient in their use of natural resources, 
namely to create a product or system that consumes less energy and materials, the use of materials that are renewable, do not use harmful ingredients, reducing unwanted output, and create products that can be recycled.

The goal of green manufacturing is: To develop products more secure, and environmentally friendly; minimizing waste of raw materials and energy; reduced liability to environmental problems; Improved cost-effectiveness in compliance with environmental regulations; to be known as a good company [9].

Many experts have been conducting research to find out the benefits obtained by the company in implementing green manufacturing. Green manufacturing positive and significant impact on the environmental performance and social performance [10]. Green operation positively impact organizational performance [11]. Green manufacturing can create lower material costs, reduce environmental costs, and improve corporate image [12].

Other researchers associate green operation with customer behavior. Consumer purchasing behavior is influenced by environmental awareness. Green products increasingly seen as important by consumers [13].

The concept of green manufacturing also affects the functioning of the supply chain management [14]. Green practices have a positive impact on improving the performance of business functions [15]. Green purchasing and green manufacturing affect the performance of procurement [16].

\section{B. Implementation of Green Manufacturing}

Implementing the concept of green manufacturing can be done by the company in several ways such as: 1). Creating products that can be recycled. There are many companies that do it yourself. In the US many companies are taking back the components of the scar; 2). Using raw materials that can be recycled; 3). Using a component that is not dangerous; 4). Using lighter components; 5). Using more energy-efficient; 6). Using fewer raw materials [17].

The green practices on manufacturing or operations functions, in the business of covering : a). Focus on profitability by using environmentally friendly operating processes; b). Plant indigenous trees, foliage, use rainwater or recycled grey water to reduce ecological damage; c). Use alternative materials and redesign operations; d). Produce durable products from design to disposal by decreasing ecological damage to ensure sustainable development; e). Find green alternatives for harmful products, at the same or improved level, at lower cost; f). Consider input costs in terms of regulations, energy use, storage and disposal; g). Reduce raw materials, energy use and toxic waste for businesses savings; h). Use eco-friendly materials, procedures and processes, and ensure optimal raw materials usage; i). Recycle waste products (e.g. plastic, paper, glass) to increase operating income and consider expansion of production capacity; j). Eliminate waste through efficient asset operations (e.g. considering a network of locations and facilities); k). Choose wisely between new and costly developments and cheaper equipment alternatives so as to ensure efficient asset operation; 1). Minimize emissions, effluents and accidents and use non-renewable forms of energy; $\mathrm{m}$ ). Use lean manufacturing to incorporate green goals into productive outcomes; $\mathrm{n}$ ). Production methods, tools and techniques must satisfy environmental requirements and market needs; o). Research and development should explore new sustainable ways of extracting raw materials and new methods to minimize energy generation and waste disposal in production processes [18].

\section{Influence of Stakeholder Pressure on the Implementation of Green Manufacturing}

Stakeholder concept, introduced by Freeman: "Stakeholders are individuals and groups which can affect the company's performance or who are affected by a firm's actions" [19].

Contemporary stakeholder perspective, taking into account the interests of the group in which the company is liable. An individual or group considered as stakeholders of a business unit when one of the three characteristics apply: (1) when the actor has the potential to positively or negatively affected by the activities of the organization or organizations related to the impact on their welfare or others. (2)When the actor can attract or provide the resources needed for the organization's activities. (3) when the actor rated by the culture of the organization [20].

Stakeholders are individuals and groups who can influence, and be influenced by the results of the strategic obtained and who have claims that can be imposed to the performance of a company [21].

Stakeholders are individuals who have an interest in the organization. The definition of interest is something of value (in the form of financial, physical or human) that bind stakeholders voluntarily or forced by the organization [22].

In this context, the position of the stakeholders voluntary or forced, to remain in the forefront. Dimensions of interest can also be selected, as follows: 1). Material interests, with regard to the fundamental interests that typically are associated with economic factors; 2). Political interests, with regard to the acquisition and use of influence or power; 30. The social interests, related to the interests of Humanitarian to be involved as a member of a group, in order to become part of a social network is a larger scale; 4). The interests of the organization, which is related to the need for data, facts, and the results of observation; 5). Spiritual interests, which leads to the opinions charged weighted values of religion and philosophy of stakeholders [23].

In this study we analyzed the effect of stakeholder pressure on the implementation of green manufacturing. Stakeholder pressure effect on the intention to carry out the implementation of green manufacturing [24]. Stakeholder pressures arise from competitor, pressure regulators (government), the pressure of customer, supplier pressure, societal pressures, and management awareness.

To explain how the stakeholder pressures affecting the implementation of green manufacturing, can be explained by the institutional theory. In the institutional theory studied how the organization can survive and succeed through harmony between these organizations and the expectations of the environment [25]. Institutional theory states that external factors (environmental and social) play an important role in influencing the company's decision to adopt a practice management [26].

Based on institutional theory, external pressure to adopt a particular practice gets legitimacy of the so-called isomorphism (isomorphism). There are three forms of isomorphism. Mimetic isomorphism is copying or imitating organizations that succeed in uncertain situations. Coercive isomorphism occurs when a given external pressure on the organization to adopt the structure, engineering or similar behavior with other organizations. This pressure can be formal or informal. Normative isomorphism includes changes to the organization to achieve the standard of professionalism, to live according to the norms of the institutional environment [27]. 
Management decisions, to adopt and implement Green manufacturing can be seen as a form of third isomorphism above. Mimetic isomorphism, is when companies implement green manufacturing in order to adapt to the same action from their competitors or other organizations to achieve success. Coersive isomorphism, occurs when companies implement green manufacturing as a response to the demand generated by the other party where their business has a high dependence, such as customers and governments. Normative isomorphism seen when companies consider implementing green manufacturing as necessary to enhance the image and reputation of their companies in the market.

Based on the explanation above, we propose the following hypotheses:

\begin{abstract}
Stakeholder pressure consisting of competitor pressures, government pressure, social pressure, customer pressure, encouragement suppliers, and management awareness, influence the implementation of green marketing in the textile companies in West Java, either simultaneously or partially.
\end{abstract}

\section{Impact of Green Manufacturing On Profitability}

The impact of the implementation of green manufacturing to profitability, occurring either directly or long term. Companies can develop new markets and increase of Reviews their market share through implementing environmental practices. As a longterm operational objectives, improved non-financial performance may be manifested by increased customer loyalty, new customers, and an enhanced image and reputation of a firm.

Previous studies showed that green innovation positive effect on the performance of companies [28]. For manufacturing firms, environmental impact score and green policies and performance score were found to have an impact on organizational performance; while, green reputation plays a more important role in impacting the organizational performance of service firms [29].

Based on the explanation above, we propose the following hypotheses:

\section{$\mathrm{H} 2$}

\section{Green manufacturing have a positive effect on profitability}

\section{RESEARCH METHODS}

This study uses a quantitative approach. The unit of analysis in this study is a company in the textile industry in West Java. A total of 102 textile enterprises are used as a randomly selected sample. Data were collected by a questionnaire compiled by the rating scale. To analyze the relationship between variables used multiple regression. Significance testing is done by using the $t$ test with $\alpha=5 \%$.

Variable implementation of green manufacturing is measured by five dimensions: 1). Creating products that can be recycled; 2). Using raw materials that can be recycled; 3). Using a component that is not dangerous; 4). Using lighter components; 5). Using more energy-efficient; 6). Using fewer raw materials.

Variable stakeholder pressure measured by 6 dimensions, namely: 1). Competitor pressures; 2). Government pressure; 3 ). Social pressure; 4). Customer pressure; 5). Encouragement suppliers; and 6). Management awareness. Meanwhile profitability measured by two indicators, namely: 1) Average net income; 2). Return on Investment.

\section{RESULTS AND DisCUSSION}

\section{A. Implementation of Green Manufacturing In Textile Industry in West Java}

Results of the study indicated that the implementation of green manufacturing in the textile industry in West Java still vary (see figure 1). The practice of green manufacturing in general is still done in the form of more efficient use of energy, which is an average of $88.16 \%$ textile industries have done. Another practice is done is to use lighter materials (82.43\%), and uses a harmless substance $(68.43 \%)$.

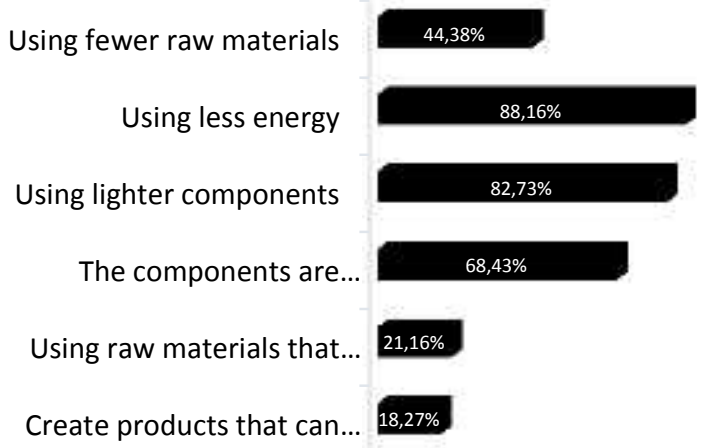

Fig. 1. Level implementation of Green Manufacturing

Meanwhile, green manufacturing practices in the form of using less material, using raw materials that can be recycled, and make products that can be recycled, they rarely do. This is evident from the percentage is still low, which use less material is $44.38 \%$, using raw materials that can be recycled is $21.16 \%$, and making products that can be recycled is $18.27 \%$.

The low implementation of green manufacturing practices, due to the nature and characteristics of the textile industry itself. Textiles difficult to find materials that can be recycled. Likewise, the products, the majority of textile products difficult to recycle. Textiles are also difficult to be transformed into materials industry with relatively fewer, because the use of materials to make the textile products difficult to reduce.

\section{B. The Effect of Stakeholder Pressure on Green Manufacturing Implementation}

In this section, we discuss the results of testing the hypothesis associative, ie, the pressure influence stakeholders on the implementation of green manufacturing. The results of data analysis using multiple regression showed that $\mathrm{R} 2$ is equal to 0.843 . It shows that simultaneously, stakeholder pressure effect of $84.3 \%$; while $15.7 \%$ is the influence of other variables that are not analyzed in this study (see Table I).

TABLE I. THE EFFECT OF STAKEHOLDER PRESSURE ON GREEN MANUFACTURING SIMULTANOUSLY

\begin{tabular}{|c|r|r|r|r|}
\hline \multicolumn{4}{|c}{ Model Summary } \\
\hline Model & $\mathrm{R}$ & $\begin{array}{c}\mathrm{R} \\
\text { Square }\end{array}$ & $\begin{array}{l}\text { Adjusted R } \\
\text { Square }\end{array}$ & $\begin{array}{r}\text { Std. Error of } \\
\text { the Estimate }\end{array}$ \\
\hline 1 & $.918^{\mathrm{a}}$ & .843 & .833 & .26014 \\
\hline $\begin{array}{r}\text { a. Predictors: (Constant), ManAware, CompPress, } \\
\text { GovtPress, CustPress, SociPress, SuppPress }\end{array}$
\end{tabular}


Simultaneously the influence is significant, with the value of F statistic, amounted to 85122 which was significant at $\alpha=5 \%$ level. (See table II).

TABLE II. TEST F TEST

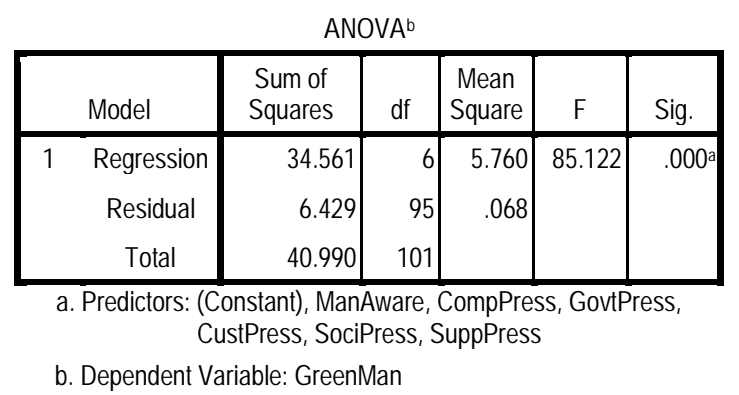

The next analysis is stakeholder pressure effect partially to green manufacturing practices. The results showed that all of the data processing stakeholder pressure positive effect on the implementation of green manufacturing (Table III).

The greatest influence on the implementation of green manufacturing is social pressure with a regression coefficient of $38.0 \%$, followed by management concern (25.3\%), and customer pressure (23.0\%). Encouragement suppliers give $16.3 \%$ influence and pressure the government to give effect to $14.2 \%$. All significant at the level $\alpha=5 \%$. However, competitor pressure, with a regression coefficient of $6.8 \%$, no significant impact on the implementation of green manufacturing.

TABLE III. IMPACT OF STAKEHOLDER PRESSURE ON GREEN MANUFACTURING

Coefficients $^{\mathrm{a}}$

\begin{tabular}{|c|c|c|c|c|c|c|}
\hline & \multirow[b]{2}{*}{ Model } & \multicolumn{2}{|c|}{$\begin{array}{l}\text { Unstandardized } \\
\text { Coefficients }\end{array}$} & \multirow{2}{*}{\begin{tabular}{|c|}
$\begin{array}{c}\text { Standardized } \\
\text { Coefficients }\end{array}$ \\
Beta \\
\end{tabular}} & \multirow[b]{2}{*}{$t$} & \multirow[b]{2}{*}{ Sig. } \\
\hline & & B & Std. Error & & & \\
\hline \multirow[t]{7}{*}{1} & (Constant) & -.389 & .207 & & -1.884 & .063 \\
\hline & CompPress & .068 & .046 & .078 & 1.478 & .143 \\
\hline & GovtPress & .142 & .058 & .126 & 2.427 & .017 \\
\hline & SociPress & .380 & .062 & .376 & 6.116 & .000 \\
\hline & CustPress & .230 & .078 & .186 & 2.932 & .004 \\
\hline & SuppPress & .163 & .081 & .148 & 2.003 & .048 \\
\hline & ManAware & .253 & .080 & .205 & 3.176 & .002 \\
\hline
\end{tabular}

The results showed that the pressure of stakeholders is a major determinant for the textile industry to implement green manufacturing. Social pressure, and management awareness, and customer pressure is the factor that most influence. It is very rational, because the three stakeholders have a very important role for the survival of the company.

Social pressure often comes from groups or communities and environmental activists [30]. Their pressure, is a form of mass publications for companies that are considered practice that is not friendly to the environment. In some cases, there is also a direct action by campaigners in the form of a boycott of products, supplies, and operating company. If that happens, of course, very detrimental to the company. The company's image will be poor due to negative publicity. Alternatively, the operations will be disrupted. Therefore, it is rational if social pressures significantly influence the implementation of green manufacturing.
Management awareness is also key to success in the implementation of green manufacturing. However, management is the key decision makers. If management has high awareness, then practice the implementation of green manufacturing will be done well.

Customer is the most important in determining the existence of the company. A good company should follow and be able to meet the demands of customers [31]. Likewise, if the customer wants a green manufacturing. There is no reason for the company, but must follow the wishes of the customer.

Although significant, the effect of government pressure is not too great for the implementation of green manufacturing. Ought to suspect is because law enforcement is still weak. The government has not been able to carry out the regulation in the context of manufacturing green firmly, so that companies do not assume government regulation as a necessary pressure got no response. Another possibility is that the products of green manufacturing regulations have not provided a complete and detailed. That is, the green manufacturing indicators have not explicitly stated in the regulation.

Pressure from competitors, does not have a significant effect. It is very rational, because each company is autonomous. That is, in the short term the company is not affected by the actions of competitors. In addition, the textile industry market nature of monopolistic competition, enables the company to operate in accordance with their particular paths, and do not put pressure on other companies.

\section{Impact of Green Manufactruing On Profitabilitas}

Next, we analyze the impact on the profitability of green manufacturing. Based on Table IV, green manufacturing a positive impact on profitability, with a $32.1 \%$ regression coefficient significant at $\alpha=5 \%$. It can be interpreted that the textile company who practice green manufacturing will gain the benefit of increased profitability.

TABLE IV. IMPACT OF GREEN MANUfACtURING ON PROFITABILITy

\begin{tabular}{|c|c|c|c|c|c|c|}
\hline \multicolumn{7}{|c|}{ Coefficients ${ }^{a}$} \\
\hline & \multirow[b]{2}{*}{ Model } & \multicolumn{2}{|c|}{$\begin{array}{c}\text { Unstandardized } \\
\text { Coefficients }\end{array}$} & \multirow{2}{*}{$\begin{array}{c}\begin{array}{c}\text { Standardized } \\
\text { Coefficients }\end{array} \\
\text { Beta }\end{array}$} & \multirow[b]{2}{*}{$\mathrm{t}$} & \multirow[b]{2}{*}{ Sig. } \\
\hline & & B & Std. Error & & & \\
\hline \multirow[t]{2}{*}{1} & (Constant) & 2.545 & .411 & & 6.199 & .000 \\
\hline & GreenMan & .321 & .101 & .303 & 3.176 & .002 \\
\hline
\end{tabular}

Green manufacturing, basically, is the company's operations based on the rule of effectiveness and efficiency with which environmental considerations are concerned [32]. The implementation of green manufacturing is the better course would bring the company to the costs savings operations. On the other hand, when the company is able to produce "green products" that customers want, then increased consumer satisfaction, corporate reputation to be positive, the customer increases, and ultimately revenues will increase.

\section{CONCLUSION AND RECOMENDATION}

This study, has gained an overview of the implementation of green manufacturing in the textile industry in West Java. In general, not all dimensions of the concept of green manufacturing is able to be implemented. Green manufacturing practices in done in the form of more efficient energy use, use of lighter materials, and using materials that are not harmful. Meanwhile, green manufacturing practices in the form of using 
less material, using raw materials that can be recycled, and make products that can be recycled, they rarely do.

Simultaneously, stakeholder pressure, is a significant factor that gives determination to the implementation of green manufacturing. Partially, social pressure, care management, customer pressure, encouragement suppliers, and government pressure positive and significant impact on the implementation of green manufacturing. Meanwhile, pressure competitors do not have a significant impact.

Green manufacturing, have a positive impact on profitability. The efficiency and effectiveness resulting from the practice green manufacturing contributed to the creation of the company's profit improvement.

Recommendations from the results of this study are as follows: 1). For the textile industry, it is proper to apply green manufacturing in their operation, as it will have an impact on profitability. 2). To be more thorough implementation of green manufacturing, stakeholders need to increase "pressure". In contrast, the textile industry need to accommodate the interests of stakeholders to happen alignment. 3). For further research, it is suggested that the discussion can be expanded, either by adding variables analyzed, or to expand the coverage and scope.

\section{REFERENCES}

[1] Supriyadi \& Ratna Ekawati. 2015. Development of Measurement Model of TQM, Innovation Capability, and Mass Customization, in Small and Medium Scale Garment Industry. Proceeding. International Cnoference in Organizational Innovation (ICOI 2015).

[2] Agustina, Rina. 2013. Analisa Hukum Terhadap Unsur Tindak Pidana Lingkungan Hidup Dalam Undang-Undang Nomor 32 Tahun 2009 Tentang Perlindungan dan Pengelolaan Lingkungan. Jurnal Beraja Niti. Vol 2 No 11 pp $1-21$.

[3] Suhendar, I., Sachoemar., Heru Dwi Wahyono. 2007. Kondisi Pencemaran Lingkungan Perairan Di Teluk Jakarta. JAI. Vol 3 . No 1. Pp 1-14. ttp://download.portalgaruda.org/article

[4] Salimath, Manjula S., Raymond Jones III. 2011. Population Ecology Theory : Implication for Sustainability. Management Decision. Vol 49. No. 6. PP 874-910.

[5] Searcy, Cory. 2011. Updating Corporate Sustainability Performance Measurement System. Measuring Business Excellence. Vol 15. No. 2. PP 44-56.

[6] Velazquez, Luis E., Javier Esquer., Nora E. Munguia., Rafael MaoureEraso. 2011. Sustainable Learning Organization. The Learning Organization. Vol 18. No. 1. PP 36-44.

[7] Deif, Ahmad M. 2011. A System Model for Green Manufacturing. Advances In Production Engineering \& Management. Vol 6. Pp 27-36.

[8] Zhou, Ming., Yanchun Pan., \& Zhinmin Chen. 2013. Green production Strategies and dynamics : A Simulation base study. Proceeding of the 2013 winter simulation conference.

[9] Heizer, Jay \& Berry Render. 2011. Operation Management. International Edition. Paerson. Prentice Hall.

[10] Sezen, Bulent., Sibel Yildiz Cankaya. 2013. Effect of green manufacturing and eco-innovation on sustainability performance. Procedia Social and behavioral science. Vol 99 (2013). 154-163.

[11] Ngiatedama, Thomas., Suhong Li. 2014. Green Operation and Organizational Performance. International Journal of Business and Social Science. Vol 5 No 3. PP 50-58.

[12] Porter, Michael E. \& Class Van Der Linde. 1995. Toward a new conception of The Environtmen-Competitiveness Relationship. The Journal of Economic Perspectives. Vol 9. No 4. Pp 97 - 118.
[13] Majlath, melinda. 2009. Evaluation of environmentally Friendly product attribute - result of an empirical research. Proceeding 7 th International conference on management, entrerprise and benchmarking. Jun 5-6. Budapest.

[14] Noor Aslinda Abu Seman, Norhayati Zakuan, Ahmad Jusoh, Mohd Shoki Md Arif. 2012. Green supply chain management : A Review and Research Direction. International journal of Managing Value and Supply chain (IJMVSC). Vol No 1. March 2012.

[15] Smith EE., S. Perks. 2010. A perceptual study of the impact of green practice implementation on the business function. Southern African business review Vol 14 No 3.

[16] Malaba, Petwa Nawire. Ogolla Kennedy., Mburu, David kiarie. 2014. Influence of green supply chain management strategy on procurement performance of sugar industry in Kenya. International journal of economics, commerce and management. Vol II, Issue 11, Nov 2014.

[17] Heizer, Jay \& Berry Render. 2011. Operation Management. International Edition. Paerson. Prentice Hall.

[18] Smith EE., S. Perks. 2010. A perceptual study of the impact of green practice implementation on the business function. Southern African business review Vol 14 No 3.

[19] Benito, Javier Gonzalez \& Oscar Gonzalez Benito. 2004. The Role of Stakeholder Pressure and Managerial Values in The Implementation of Environmental Logistics Practices. Research Project SEJ 200403888/ECON

[20] Ferrell, OC, Tracy L Gonzales-Padron, G Thomas M Hult, \& Isabelle Maignan. 2010. From Market Orientation to Stakeholder Orientation. Journal of Public Policy \& Marketing. Vol 29 (1). Pp 93-96. American Marketing Association.

[21] Hit, Michael A. R. Duane Ireland., Robert E. Hoskisson. 2001. Manajemen Strategis. Daya Saing \& Globalisasi. Terjemahan. Penerbit Salemba Empat. Jakarta.

[22] De Bakker, Frank., Frank den Hond \& Renee Van der Plas. 2002. Stakeholder Influence Strategies and Stakeholder-Oriented Management. The $10^{\text {th }}$ Greening of Industry Network Conference Goteburg, Sweden, 23-26 June 2002.

[23] Heene, Aime., Sebastian Desmidt., Faisal Afiff., Ismeth Abdullah. 2010 Manajemen Strategik Keorganisasian Publik. Cetakan Kesatu. Refika Aditama.

[24] Weng, (Robin) Hua-Hung., Ja-Sen Chen., Pei-Ching Chen. 2015. Effects Green Innovation On Environmental and Corporate Performance : A Stakeholder Perspective. Sustainability. Vol 7. DOI 10.3390/su7054997.

[25] De Bakker, Frank., Frank den Hond \& Renee Van der Plas. 2002. Stakeholder Influence Strategies and Stakeholder-Oriented Management. The $10^{\text {th }}$ Greening of Industry Network Conference Goteburg, Sweden, 23-26 June 2002.

[26] Prajogo, Daniel I. 2011. The Role of firms' Motives in Affecting the Outcomes of ISO 9000 Adoption. International Journal of Operation \& Production Management. Vo. 31 No. 1 pp. 78-100.

[27] De Bakker, Frank., Frank den Hond \& Renee Van der Plas. 2002. Stakeholder Influence Strategies and Stakeholder-Oriented Management. The $10^{\text {th }}$ Greening of Industry Network Conference Goteburg, Sweden, 23-26 June 2002.

[28] Weng, (Robin) Hua-Hung., Ja-Sen Chen., Pei-Ching Chen. 2015. Effects Green Innovation On Environmental and Corporate Performance : A Stakeholder Perspective. Sustainability. Vol 7. DOI 10.3390/su7054997

[29] Ngiatedama, Thomas., Suhong Li. 2014. Green Operation and Organizational Performance. International Journal of Business and Social Science. Vol 5 No 3. PP 50-58.

[30] Daft, Richard, L. 2000. Manajemen. Edisi kelima. Penerbit Erlangga. Jakarta.

[31] Robbins, Stephen P., \& Mary Coulter. 2010. Manajemen. Edisi kesepuluh. Jilid 1. Penerbit Erlangga.

[32] Finch, Byron J. 2008. Operations Now. Supply Chain Profitability and Performance. Third Edition. McGraw Hill International Edition. 